\title{
Processing the Children Dealing with the Law Accordance Indonesian Act on Juvenile Justice System Number 11 of 2012
}

\author{
Putu Wisnu Nugraha ${ }^{1} \&$ I Nyoman Putu Budiarta ${ }^{2}$ \\ Universitas Warmadewa, Denpasar-Bali, Indonesia
}

\begin{abstract}
With normative study design, we examined the processing of children dealing with law in consonance with Inonesian juvenile justice. We also explored the renewal of criminal law in the processing of the children. We found that: firstly, the problematic children with the law are processed with a flow of activities covering, investigating, examining, and prosecuting them in court proceedings to the implementation of court decisions. Second, criminal law related to juvenile justice law seems to have to be amanded through a policyoriented approach and a value-oriented approach. It is because, in essence, such an act amandement is indeed only a part of policy steps covered in legal politics or law enforcement, criminal law politics, criminal politics, and social politics.
\end{abstract}

Keywords: Juvenile Justice System, Children, Protection

\section{Introduction}

The social facts that have recently occurred in society are child-related problems. In the continuity of social life, which is influenced by various factors, the community is often faced with matters involving children who are suspected of committing criminal acts $[1,2,3,4]$. The children are the foundation of the hopes of the future of the nation, country, society or family [5], they should not be made a subject of unfair legal contents. Thus, in the status and circumstances as a child, every child must be specifically treated, in order to allow them grow mentally, spiritually, and physically [6].

Children are part of the younger generation as human resources who have the potential and are responsible for continuing the ideals of the nation's struggle in the future [7]. Children are figures who have a strategic role and have special traits and characteristics, need guidance and protection in order to ensure balanced growth, physical, mental and social development [8]. Childhood is a period of seed sowing, the establishment of piles, the making of foundations, which can also be called a period of character formation, personality and character in a human being, so that they will later have strength and ability and stand firm in pursuing life [9].

Children being dealth with law will be tightly bound to the rules of law that govern it, in which initially the applicable rules in Indonesia cannot be separated from international instruments, which are related to the fulfillment of children's own rights. Convention on the rights of the child is the one adopted on November 20, 1989 and written in the United Nations Resolution No. 44/25 (Convention on the Rights of the Child). The Government of the 
Republic of Indonesia has then ratified it with Presidential Decree No. 36 of 1990. In its essence, it has an extended meaning in the context of child protection, including for children who have problems with the law.

The process of handling children who commit criminal acts in Indonesia has regulations regarding prosecution procedures in juvenile justice [10]. In handling children, the police have a legal authority, called discretion, where with that authority, they have the right to continue or not continue a case [11]. The possibility for the police to carry out or use this discretionary authority is enormous. In some countries, after going through an initial inspection, the police's discretion authority can determine the form of transfer (diversion) of a child case. Discretion is the authority possessed by the police to stop case investigations by freeing child suspects, or transferring (diversion) with the aim that children avoid further legal processes [12].

In her dissertation, Sepud claimed that Indonesian Act of criminal justice system of children is adapted to legal protection for children in the International Convention that is of United Nations. Minimum Standards of Rules for Non-Custodial Measures (The Tokyo Rules); United Delinquency (The Riyadh Guidelines); and the United Nations Minimum Rules for Administration of Juvenile Justice (the Beijing Rules) on Diversion so that Law Number 11 of 2012 is in accordance with the contents of international conventions on children's rights [13].

Regarding the earlier elaboration, the present study examines the vagueness of norms contained in article 5 paragraph (3) and article 7 of Indonesian Act of juvenile system, Number 12 of. Particularly, the study examines the processing of children dealing with the law and the amandement on Indonesian criminal law in the processing of children with legal problematic.

This study examines the vagueness of norms regarding diversion in Law No. 11 of 2012 concerning the Juvenile Justice System, where in this case the positive rules of Indonesia do not pour International Instruments, which have been ratified in Positive rules in Indonesia. This study uses a normative legal research design. Some of the approaches used in this study are case approach, statute approach, and analytical \& conceptual approach. Material collection was carried out using notes from the results of research conducted on several norms (positive rules), books, or existing literature with the problems discussed. Then, the legal materials were reviewed with the concepts, thoughts, or opinions of several legal experts and examine them with theories relating to the issues to be discussed, especially regarding criminal law renewal policies for children who have problems with law. Data were analyzed by techniques of description, interpretation, evaluation, and argumentation. We made sense on the collected data by providing descriptions based on legal prescriptions related to juvenile justice system and criminal committing children. We also made interpretions on the data in order to provide comprehensive version of the legal provisions realisation in conjuction with handling process of children committing criminal acts. Additionally, by basing on the enacted legal rules for processing disputes of criminal acts commited by children, we made evaluations to verify the sync nature between them. To each expalantion, we gave argument in discussing between prescribed rules of law concerning juvenile justice system and conditions to which children are liable to their criminal acts.

\section{Results and Discussion}

\section{Processing of Children in Indonesian}

A judicial process represents a juridical process, where there must be an opportunity for everyone involved in a legal case to discuss and each of them can fight for a certain position in issuing an opinion that is expressing the interests of various parties, considering it and the 
decisions taken are partially motivating [14]. The processing of children being confronted with legal justice is closely related to the enforcement of the law itself, in line with the principles in the justice system. The principle of the criminal justice is in line with what was stated by Dellyana, that is to say, it is "the system of enforcing the power of criminal law" realized in 4 subsystems, namely:

a. Authority of "Investigation" (by Investigating Agency/Institution)

b. Authority of "Prosecution" (by Public Prosecutor/Institution)

c. Authority of "Trial and Decision/Crime" (by the Court)

d. Authority of "Implementation of Criminal Decision" (by the Implementing Agency/Execution) [15].

Starting from this concept, the process of handling children before the law for their committed crimes is inseparable from regulations that contain material and formal laws related to cases, namely Law Number 11 of 2012 concerning the Juvenile Justice System. In its empirical facts in Indonesia, this norm rule has not been able to fulfill the objectives of the Law itself, which is oriented towards "the best interests of the children". Law No. 11 of 2012 which is the ius constitutum concerning the Juvenile Justice System is currently ineffective as outlined in the consideration and explanation of the Law itself. The provisions that do not provide space and a way out to conduct discretion and diversion to the judge after seeing the assessment of the Correctional Center cause this. In fact, discretion and diversion are security groups for children of certain offenders, which aim to avoid children with legal disputes from the conventional process of the juvenile justice system, which usually has a negative impact on the occurrence of stigmatization in children. Law No. 11 of 2012 at the level of ius operatum in the provisions of Law Number 11 of 2012, law enforcement has not been able to be carried out by law enforcement officers who are professional in the field of child protection as desired by the law itself. In criminology studies, stigmatization experienced by children becomes a trigger factor for criminogen in repeating the next delinquency.

Luckily, the results of this study lead us to bring about an applicative conclusion. We found the strategically alternative solution to deal with children in disputes. We draw conclusions from the understanding of existing norms containing obscurity in a sense that existing legal norms are not effectively able to provide holistic protection to legally blind children to the right and not right conduct in the eyes of the law. Therefore, we offer strategies to solve legal problems of children in dispute through interpretation. This concept is inspired by what Bruggink once said about the form and type of interpretation. An interpretation can be realized in:

a. Detaalkundige interpretatie (language interpretation)

b. De wetshistorische interpretatie (history of law)

c. De systematische interpretatie (systematic)

d. De maatshappelijke interpretatie (community) [16].

The vagueness of the norms is seen at times the investigators determine other actions, such as bringing back the children to their parents/custodian. For children who have problems with the law as stipulated within juvenile system, number 11 of 2012, investigators like law enforcement officers who have an authority or discretion in handling the criminal justice system in children facing the law, can take advantage of other actions to complete the children handling process. Based on the study of Justice Theory in law enforcement, as introduced by 
Radhruch, law enforcement in Juvenile Justice should have the value of justice and benefit so that efforts to achieve legal certainty are attainable. Compared with Radhruch's notion of law enforcement, to rectify the vagueness of norms, harmonization should be carried out. Furthermore, with regard to the obscurity of the norm, in the perspective of Law Enforcement theory, law enforcement is a process carried out to seek legal norms to function and to be as firm as possible in a real term, to become a guideline for community behavior related to law. Law enforcement itself is actually a systematic process, in the concept that it involves a regular, well-planned, and intact process to realize the desires of the law (the thought of the legislative body formulated in legal regulations) becomes a conceptual reality. In conclusion, the core and intrinsic meaning of law enforcement lies in the activity of harmonizing the relationship between the values outlined in the rules that are realized in the form of legislation. In the substance of the concept of law enforcement theory, as stated also by Rahardjo, to achieve a good and efficient law enforcement effort, it should start from a good norm and the form of legislation. To succeed the law enforcement efforts maksimally, the efforts made must begin by harmonizing the norms in which the vagueness existis. This is as a comparison as echoed by the hitoris interpretation of legislation itself. In this context, the Act number 11 of 2012 is the embodiment of one of the international conventions on children, especially The Beijing Rules, so that the legality in carrying out other actions in the form of returning children to parents/custodians is brought closer to The Beijing Rules, especially that of in 20.1 .

\section{Indonesian Criminal Law Renewal in the Process of Handling Children with Legal Problems in the Perspective of Ius Constituendum}

Criminal law amandement is essentially an effort to reorient it to the socio-political, socio-philosophical, socio-cultural values of the society that underlie social, criminal and law enforcement policies. Principally, the law shall be amended with policy-oriented approach and a value-oriented approach [17]. It needs to becarried out with these approaches because in principle it is only part of a "policy" steps and a part of the legal politics. Each policy involves consideration of values. Thus, renewal of criminal law must also be oriented towards a value approach.

The fact about the condition of the realization of law in the community supports the assessment that the community should feel significant differences. Unfortunately, what revealed was something that was in line with Rahardjo's idea: in the real life context of society, differences between legal functions before and after independence were not found. The difference lies only in the political decisions taken in both periods and their implementation into their respective legal systems. In the Indonesian context, if the political decisions taken after the independence of August 17, 1945 were to prioritize the greatest prosperity of the people, such decisions must be formulated in legal rules and the legal structure must provide the possibility to do so [18].

The essence of criminal law renewal therefore is inseparable to the theory of legal protection and the theory of punishment. The legal protection in renewing criminal law rests on and derives from the concept of recognition and protection of human rights. This is because according to history the birth of the concept of recognition and protection of human rights is directed to the limitations and lying down of the obligations of society and government. For the principles of legal protection in Indonesia, the foundation is Pancasila, as an ideology and state philosophy, and thus, the Law number 11 of 2012 concerning the Juvenile System represents the legal protection in accordance with the ideology and philosophy of the state. This is in accordance with his opinion Rahardjo who argues that legal protection is an effort to 
protect the interests of a person by allocating a power to him to act in these interests [18]. Related to the criminal theory used by the author as an analytic tool to examine the problems regarding renewal of criminal law, this theory is used as a basis in the application of criminal sanctions. There are three side-by-side theories: Rewards Theory, Purpose and Purpose Theory, and Combined Theory. Based on these three theories, many experts provide different views. The conclusion is that punishment is imposed to carry out the intent and purpose of a particular sentence; creating and creating the greatest happiness for everyone according to his or her views. Additionally, this is also in line with Bentham's idea, vis-à-vis, the purpose of law is to achieve "happiness for the welfare of large numbe of community." Thus, an important factor in the renewal of Indonesian criminal law lies in notion that the punishment received from a child who commits a criminal act is not always manifested in criminal sanctions, but can also manifest in other actions aimed at protecting children as community cadres - actions that might be detrimental to a child's life in the future.

\section{Conclusion}

The process of handling children facing the law in the Child Criminal Justice System is a judicial process carried out at the level of investigation, investigation, prosecution, examination in the court until the implementation of the court's decision. During the judicial process, applicable law must protect children's rights, and therefore, the parties related to solving the problem of the bad boy must carry out the handling process consequently. Therefore, at the time of the examination, an investigator does not wear a uniform or service and takes an effective, active, and sympathetic approach. Speaking of investigating children, we will talk about the authority regulated according to Article 5 paragraph (2) and (3) Law Number 11 of 2012.

Amendment to Indonesian criminal law contain efforts to reorient and reform criminal law in accordance with the socio-political, socio-philosophical, socio-cultural values of the Indonesian people that underlie social policies, criminal policies and law enforcement policies. Therefore, it shall be done through a policy-oriented approach and on value. That is because each policy involves value judgments.

\section{Acknowledgement.}

The authors express the greatest gratitude to the organizing committee of the International Conference on Social Sciences (ICOSS) of Universitas Warmadewa for the great contribution that has been granted to the launching of this scientific script at EAI Publisher. We hope that the ideas found in the paper can be additional to the theoretical and practical konwledge for many parties.

\section{References}

[1] W. R. Smitht and M. F. Aloisi, “SECOND TIMERS' IN THE JUVENILE JUSTICE SYSTEM: Efficiency in Screening Chronic Offenders," Am. J. Crim. JUSTICE, vol. 23, no. 2, pp. 201-222, 1999.

[2] V. Kumari, "The Juvenile Justice System in India : From Welfare to Rights," Springer Sci. Media, vol. 1, no. 2006, pp. 209-211, 2006.

[3] B. R. B. Mcnally, A. Juvenile, F. C. Journal, and R. B. Mcnally, "Nearly a Century Later: The Child Savers - Child Advocates and the Juvenile Justice System," Juv. Fam. Court J., pp. 47-52, 1982.

[4] P. D. Kurtz, D. Ph, M. M. Giddings, D. Ph, R. Sutphen, and D. Ph, "A Prospective Investigation of Racial Disparity in the Juvenile Justice System," Juv. Fam. Court J., 
1993.

[5] R. Phyllis, "Leaving the Family Out of Family Court: Criminalizing the Juvenile Justice System," Amer. J. Orthopsychiat., vol. 48, no. July, pp. 390-393, 1978.

[6] D. Prinst, Hukum Anak Indonesia (Selanjutnya disebut dengan Darwan Prinst I). Bandung: PT. Citra Aditya Bakti, 1997.

[7] H. Services and R. Tape, "The Impact of Time on Parent Perspectives on the Barriers to Services and the Service Needs of Youths in the Juvenile Justice System," Juv. Fam. Court J., pp. 41-49, 2002.

[8] L. Primasari, Keadilan Restoratif Dan Pemenuhan Hak Asasi Bagi Anak Yang Berhadapan Dengan Hukum. 2009.

[9] M. Gultom, Perlindungan Hukum Terhadap Anak dalam Sistem Peradilan Pidana Anak di Indonesia. Bandung: Refika Aditama, 2008.

[10] A. Agustina, Setiono, and Artiwiningsih, "STRENGTHENING THE LEGAL PROTECTION FOR CHILDREN IN CONFLICT WITH THE,” Int. J. Business, Econ. Law, vol. 13, no. 4, pp. 74-81, 2017.

[11] I. Jauhari and M. Hum, "A Comparison of Child Protection Law between Indonesia and Malaysia,” IOSR J. Humanit. Soc. Sci. Ver. IV, vol. 2029, no. 21, pp. 2279-837, 2015.

[12] A. J. Deangelo, "Diversion Programs in the Juvenile Justice System: An Alternative Method of Treatment for Juvenile Offenders," Juv. Fam. Court J., pp. 21-28, 1988.

[13] I. M. Sepud, Kebijakan Legislatif terhadap Perlindungan Hukum Anak yang Berhadapan dengan Hukum dalam Sistem Peradilan Pidana Anak Melalui Diversi. 2014.

[14] S. Dellyana, Wanita Dan Anak Dimata Hukum. Yogyakarta: Liberty, 1988.

[15] B. N. Arief, Kapita Selekta Hukum Pidana tentang Sistem Peradilan Pidana Terpadu (Selanjutnya disebut dengan Barda Nawawi Arief V). Semarang: Badan Penerbit Universitas Diponegoro, 2006.

[16] S. Mertokusumo, Penemuan Hukum Suatu Pengantar. Yogyakarta: Liberty, 2001.

[17] B. Nawawi, Bunga Rampai Kebijakan Hukum Pidana (Selanjutnya disebut dengan Barda Nawawi Arief VII). Semarang: Universitas Diponegoro, 1994.

[18] "Masalah-masalah Hukum," Fak. Huk. Undip, vol. XII, no. 5-6, 1982. 